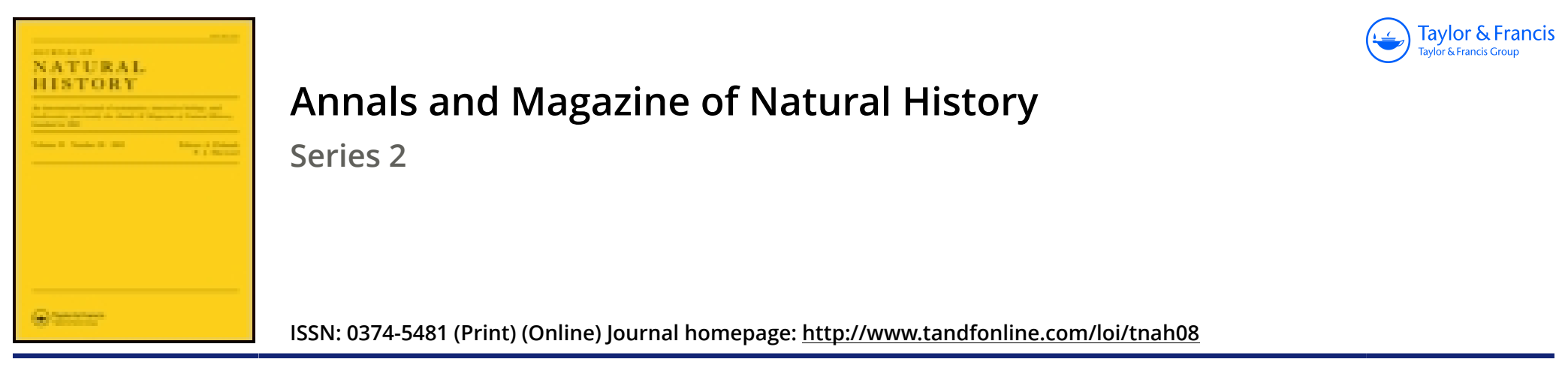

\title{
XIV.-On the identification of the parasitic genus of insects, Anthophorabia
}

\section{George Newport Esq. F.R.S. L.S.}

To cite this article: George Newport Esq. F.R.S. L.S. (1849) XIV.-On the identification of the parasitic genus of insects, Anthophorabia, Annals and Magazine of Natural History, 4:20, 122-124, DOI: $10.1080 / 03745486009496157$

To link to this article: http://dx.doi.org/10.1080/03745486009496157

\section{册 Published online: 23 Dec 2009.}

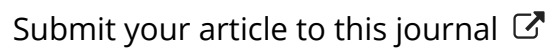

Џ Article views: 2 
XIV.-On the Identification of the Parasitic Genus of Insects, Anthophorabia. By George Newrort, Esq., F.R.S. \& L.S.

To the Editors of the Annals of Natural History.

Gentlemen,

London, July 1849.

Mr. Westwoon's letter, inserted in your July number, in reply to my remarks on the identification of Anthophorabia, obliges me to trouble you with some further remarks on this subject.

I mentioned in my letter to you, that immediately after the reading of my paper to the Linnæan Society, on the 20th of March, "the good faith of my statements (was) abruptly questioned in some remarks addressed to the Society by Mr. John Obadiah Westwood, who made it appear that my knowledge of the insect Anthophorabia must have been derived from vivâ voce statements made by himself at a meeting of the Entomological Society in July 1847 " (Annals, vol. iii. p. 514). Mr. Westwood now, after professing that he " has neither leisure nor inclination to answer in detail,"-which very probably he has not,- -says, "I again deny having expressed a single word of doubt as to Mr. Newport having found the insects in question in 1832 , or that $I$ asserted that his knowledge of them was derived from my communications." Now I beg to say, that whatever may have been the precise words employed, Mr. Westwood most certainly did express doubt, and did impress, and did endeavour to impress on the minds of those who were present, that my first knowledge of the insect I had described must have been derived from his observations at the Entomological Society in July 1847; and he asserted, in the most positive manner, that I was in the Chair at the time. The printed Proceedings of the Society prove that Mr. Spence was in the chair! I may now further state, that he succeeded, for the time, in injuring me in the good opinion of many who were present at the Linnæan Society, as I have since been assured by several gentlemen; as his imputations seemed to be supported by the fact-which he still dwells upon, with what object others may decide (Annals, p.39) - of my having been present at the meeting of the Entomological Society when he referred to an insect by the name of Melittobia Audouinii; although, to this very hour, I have never seen that insect or his drawings of it. Further, I may mention that it was evidently his object to question the accuracy of my statements in the paper I read to the Linnæan Society which drew forth the spontaneous evidence in my favour from Mr. Nash, as I have since been assured by that gentleman, to whom I had shown drawings of my insect in 1832. These identical drawings, which I made from living specimens, and which I regard as some of the most care- 
fully finished $\mathrm{I}$ have ever made, were on the table of the Linnæan Society when my paper was read, on the 20th of March, and also on the lst of May; on which latter occasion they were examined for a fow minutes only by Mr. Westwood. Yet he now makes the following assertion : "Having seen Mr. Newport's drawings made seventeen years ago, I do not hesitate to state that his description has been drawn up from this imperfect sketch (!), and that seven out of the nine generic characters given by him in the 'Gard. Chronicle,'p. 183, are erroneous." Indeed! Seven characters erroneous!! Mr. Westwood's former statement (Gard. Chronicle, p. 295) was, that six out of nine were wrong. But now he discovers "seven,"-size of the head, the antennæ, the wings, and the tarsi of the female, antennæ and eyes of the male, and size of the insect. Truly, here are seven. First then as regards size. I have described my insect as being of the Lilliputian dimension of one line. Mr. Westwood says, No, it is exactly three-quarters. Many thanks for this, and the other equally important corrections, if confirmed. I have said the head of the insect is wider than the thorax. Mr. Westwood says it is not. According to him, I have overlooked some joints in the antennæ and some peculiarities of the wings. Possible, certainly. But the admission of the possibility is not an assent to the assertion, without proof. In the tarsi, however, he thinks that I have seen too much.

As to the male insect he asserts that it has no eyes whatever, but that it has more joints in its antennæ than I have described. Yet in all this, while affirming the identity of his insect with mine, he keeps out of view the fact that the one he refer's to is a native of France, and that which I have described is indigenous to this country; and that the middle portion of the antenna in my insect is "large and globose," while the corresponding part in his, according to his description, is "very small and subannulose." Nevertheless he "does not hesitate" to "reaffirm" the identity of two insects, one of which he has never seen! But further, he "affirms," and possibly may hereafter "reaffirm," that some of the characters I have given for my insect, "namely the veins of the wings and the five-jointed tarsi, neither belong to the family nor subfamily to which the insect is to be referred, whilst the possession of stemmatous eyes by the male is disproved by every known species of winged insect, whereas it is as essentially a character of some of the Ametabolous tribes." According to this lucid view, which seems to have been arrived at through one of Mr. Westwood's "strikingly opposite analogies," if a winged insect has not compound eyes it cannot have eyes at all. Now it was the peculiarity of my insect possessing stemmatous eyes that led to the introduction of a description of it in 
my paper. With regard to the joints of the tarsi, it happens, unfortunately for Mr. Westwood, that he is in this instance, at least, in the unenviable situation of bearing evidence against the correctness of his own statements. Ten years ago he published in his 'Introduction,' vol. ii. Generic Synopsis, p. 73, detailed definitions of three genera of Parasitic Hymenoptera belonging to the very family, - Chalcidida, proposed also by himself,- - to which my Anthophorabia belongs; and one of the characters which he employs to indicate each of these genera,-Tetracnemus, Agonioneurus, - which comprises thirteen species, - and Coccophagus three species,-is, that their tarsi are "five-jointed."

Thus much reliance may be placed on the scientific accuracy of Mr. Westwood's statements. I have now but to notice.one other of his unnecessary assertions, of a more personal character, and which I could have wished to have believed to be simply accidental. He says (Annals, p. 40) that Mr. F. Smith was the first to discover the parasitic larva of Monodontomerus, and that I have "attempted to deprive him of the credit" of this discovery. I regret much that this direct charge obliges me to state that $\mathrm{Mr}$. Westwood asserts in this what is extremely wide of the truth. A short notice of the habits of the larva of Monodontomerus was sent by Mr. Smith to the Linnæan Society a fortnight after the reading of the first part of my paper on the 20th of March in which I described this larva; and that notice was read on the 3rd of April, Mr. Smith the author of it, Mr. Westwood and myself being present. Mr. Smith stated in his paper that he had found his insects at Charlton in Kent, in 1848. After this paper had been read, I mentioned what I had already stated in my paper on the 20th of March, that I discovered the larva of $\mathrm{Mo}$ nodontomerus on the 12th of September 1847 (at Gravesend), "that I had informed Mr. Smith at the time of the fact," and that "some time afterwards, as I learned from Mr. Smith himself, who, being present, could correct me if in error, he also collected larvæ of this insect in the same locality" (see Gard. Chron. April, p. 231). Mr. Smith offered not the slightest remark on, or objection to this statement, but tacitly admitted its correctness. And yet Mr. Westwood having heard this public announcement from my own lips, and knowing that it has appeared in print,as he quotes a portion of the identical paragraph,-and knowing also that it cannot be refuted, has ventured to "affirm" the contrary.

I remain, Gentlemen, yours very obediently, George NeWport. 